\title{
Evaluation of Antioxidant Activity of Banana Peels (Musa acuminata) Extracts Using Different Extraction Methods
}

\author{
SANDHYA SINGH and POONAM PRAKASH
}

Department of Chemistry, School of Basic Sciences Sam Higginbottom Institute of Agriculture, Technology \& Sciences (Deemed-to-be-University) Allahabad -211007, India chauhansandhyanaini@gmail.com

Received 31 July 2014 / Accepted 5 September 2014

\begin{abstract}
The present study was aimed for the evaluation of antioxidant activity of crude extracts [(acetone, methanol: chloroform (3:2) and ethyl acetate] of banana peels obtained by Soxhlet (hot extraction) and soaking (cold extraction) methods. The antioxidant activity of these extracts was determined by DPPH (1, 1- Diphenyl - 2- picrylhydroxyl) assay method. It was found that free radical scavenging activity of banana crude extracts was significantly higher in acetone extract among all the extracts studied. On comparing the activities of peel extract of Soxhlet and soaking it was found that the activity of peels extracts of Soxhlet was higher than soaking extracts. All the extracts showed lower antioxidant activity compared to ascorbic acid used as standard.
\end{abstract}

Keywords: DPPH assay, Ascorbic acid, Antioxidant activity

\section{Introduction}

Fruits and vegetables are an important component of a healthy diet. The currently accepted scientific names for most groups of cultivated bananas are Musa acuminata. They are known as a weak primary antioxidant source but a powerful secondary antioxidant source ${ }^{1}$. It is one of the world's leading food crops with a great source of minerals, vitamins, carbohydrates, flavonoids, phenolic compounds etc. ${ }^{2}$. India is contributing $27 \%$ to the world for banana production $^{3}$. The peel of banana represents $40 \%$ of the total weight of the fruit. Peel contains potassium $(\mathrm{K})$, calcium $(\mathrm{Ca})$, sodium $(\mathrm{Na})$, iron $(\mathrm{Fe})$, manganese $(\mathrm{Mn})$, Copper $(\mathrm{Cu})$, bromine, rubidium, strontium, zirconium and niobium ${ }^{4}$. Bananas are one of the few fruits that ulcer patients can safely consume. Bananas not only relieve painful ulcer systems and other intestinal disorders ${ }^{5}$. Banana peel, an underutilized source of phenolic compounds is considered as a good source of antioxidants for foods and functional foods against cancer and heart disease ${ }^{6}$. Banana peels equivalent to $40 \%$ of the total weight of fresh banana, are generated as a waste product in industries producing banana based products ${ }^{7}$. The research on banana (Musa acuminata) peel extract indicated that banana peel is potential source of bioactive compounds like flavonoids and polyphenols with wide range of medicinal properties in particular the high free radical scavenging activity ${ }^{8}$. Banana peel may have capability to extract heavy metal contamination from river water ${ }^{9}$. 


\section{Experimental}

Banana fruit was collected from the local market of Allahabad. Bananas were washed under the tap water and peels were separated from the pulp and cut into small pieces for the extraction. Extraction was done by two methods and the solvents are ethyl acetate, chloroform and methanol (3:2) and acetone:

1 Cold extraction by soaking method

2 Hot extraction by Soxhlet method

\section{Soaking method}

Sample (110 g) was soaked into each solvent separately for $48 \mathrm{~h}$ inside a conical flask. The resulting extracts were filtered and then distilled. The obtained extracts were obtained and sealed with aluminum foils and stored in the refrigerator at $4{ }^{\circ} \mathrm{C}$ until required for antioxidant activity.

\section{Soxhlet method}

$110 \mathrm{~g}$ of Peel sample obtained was taken for different solvents separately and the extractions were carried out for $32 \mathrm{~h}$ at $40^{\circ} \mathrm{C}$. The solvents in the extract were removed under reduced pressure at $40{ }^{\circ} \mathrm{C}$ using rotary evaporator. The obtained extracts were sealed with aluminum foils and kept in the refrigerator at $4{ }^{\circ} \mathrm{C}$ until required for antioxidant activity.

\section{Antioxidant activity by DPPH radical scavenging assay}

Different dilution of extract (200,400,600 and $800 \mu \mathrm{g} / \mathrm{mL})$ was prepared. DPPH solution was prepared by dissolving $6 \mathrm{mg}$ of DPPH in $100 \mathrm{~mL}$ ethanol then $2 \mathrm{~mL}$ of extract from each dilution was added ethanol into $2 \mathrm{~mL}$ of DPPH solution. Ascorbic acid was used as standard. The mixture was shaken vigorously and was left to stand in the dark for 30 minute. The absorbance of the resulting solution was measured spectrophotometrically at $517 \mathrm{~nm}$. The scavenging activity of the extract was calculated using the formula: Scavenging activity $\%=$ $100 \times(1-\mathrm{AE} / \mathrm{AD})$, Where AE is absorbance of the solution, when extracts has been added at a particular level and AD is the absorbance of the DPPH solution, without extract (control) ${ }^{10}$.

\section{Results and Discussion}

\section{Antioxidant activity}

Extracts of banana peels (musa acuminata) posses antioxidant activity. Banana peels extracts were studied by free radical scavenging assay method. This is based on UV Visible absorption spectrophotometric method. Its maximum absorption wavelength is $517 \mathrm{~nm}$. From Table 1 among all the extracts of banana peel, in cold extraction method the acetone extract at the concentration of $800 \mu \mathrm{g} / \mathrm{mL}$ exhibited the highest free radical scavenging potential (65.91\%), followed by chloroform:methnol (3:2) extract (60.85\%) and ethyl acetate extract (50.55\%). Similarly among all the extracts of banana peel in hot extraction method the acetone extract at the concentration of $800 \mu \mathrm{g} / \mathrm{mL}$ exhibited the highest free radical scavenging potential (72.83\%), followed by chloroform:methnol (3:2) extract (68.48\%) and ethyl acetate extract (57.28\%). On comparing the activities of different extracts it was found that the activity obtained in the cold extraction method (soaking) is lower that the activity obtained in the hot extraction method (Soxhlet) similar results were observed by Shivashankar et $a l^{11}$. It was observed that acetone extract showed better result in both the extraction method. This may be due to more polarity compared to other extract of Musa acuminata peel (Banana). Polarity of acetone, chloroform: methanol (3:2) and ethyl acetate are 5.1, 4.7 and 4.4 respectively. Polarity of solvents indirectly played a vital role in extraction process since it would increase the solubility of antioxidant compounds ${ }^{12}$. On the 
basis of results obtained, it can be concluded that DPPH free radical scavenging assay method of Musa acuminata showed that Soxhlet method was more effective in comparison to soaking method because in Soxhlet extraction method, bioactive compound is extracted with solvents and once it is extracted, it did not come in contact with the mother impure solid, only solvent vapours move from the mother impure solid. In soaking extraction method, extract always remain in the contact of mother impure solid as compared to Soxhlet. So Soxhlet extract showed better antioxidant activity in comparison to soaking extract ${ }^{13}$.

Table 1. DPPH free radical - scavenging activity assay of all the extracts by both extractions (soaking and Soxhlet) in all the three solvents

\begin{tabular}{|c|c|c|c|c|c|c|c|}
\hline & \multicolumn{7}{|c|}{ \% Inhibition of different extracts } \\
\hline & \multicolumn{2}{|c|}{ Acetone Extract } & \multicolumn{2}{|c|}{$\begin{array}{l}\text { Chloroform : methanol } \\
\text { Extract }(3: 2)\end{array}$} & \multicolumn{2}{|c|}{ Ethyl acetate Extract } & \multirow[t]{2}{*}{$\begin{array}{l}\text { Ascorbic } \\
\text { Acid }\end{array}$} \\
\hline & Cold & Hot & Cold & Hot & Cold & Hot & \\
\hline $\begin{array}{l}\text { Conc. } \\
\mu \mathrm{g} / \mathrm{mL}\end{array}$ & $\begin{array}{c}\text { Extraction } \\
\text { nm }\end{array}$ & $\begin{array}{c}\text { Extraction } \\
\text { nm }\end{array}$ & $\begin{array}{l}\text { Extraction } \\
\text { nm }\end{array}$ & $\begin{array}{l}\text { Extraction } \\
\text { nm }\end{array}$ & $\begin{array}{c}\text { Extraction } \\
\mathrm{nm}\end{array}$ & $\begin{array}{c}\text { Extraction } \\
\mathrm{nm}\end{array}$ & $\mathrm{nm}$ \\
\hline 200 & 26.197 & 28.30 & 13.16 & 20.59 & 12.91 & 14.07 & 68.86 \\
\hline 400 & 47.32 & 54.33 & 36.65 & 38.73 & 34.58 & 35.92 & 82.05 \\
\hline 600 & 54.64 & 62.42 & 52.32 & 59.68 & 40.68 & 52.18 & 82.72 \\
\hline 800 & 65.91 & 72.83 & 60.85 & 68.48 & 50.71 & 57.28 & 83.72 \\
\hline
\end{tabular}

\section{Conclusion}

It is concluded that DPPH free radical scavenging assay method of Musa acuminata showed that the activity obtained in the Cold extraction method (soaking) is lower that the activity obtained in the hot extraction method (Soxhlet).

\section{References}

1. Haripyaree A, Guuneshwor K and Damayanti M, Electronic J Environ, Agr Food Chem., 2010, 9, 345-450.

2. Guyle ne A, Berthe P and Louis F, Trends Food Sci Technol., 2009, 20(2), 78-91; DOI:10.1016/j.tifs.2008.10.003

3. $\quad$ Mohapatra D, Mishra S and Sutar N, J Scientific Industrial Res., 2010, 69(5), 323-329.

4. $\quad$ Gulizar K and Sibel Y, Extraction J Agr Food Chem., 2011, 47, 4638-4644.

5. Sampath K, Bhowmik D, Duraivel S and Uma D M, J Pharmacognosy Phytochem., 2012, 1, 57-70.

6. Someya S, Yoshiki Y and Okubo K, Food Chem., 2002, 79(3), 351-354; DOI:10.1016/S0308-8146(02)00186-3

7. Zhang P, Whistler R L, Be Miller N and Hamaker B R, Carbohydrate Polymers, 2005, 59(4), 443-458; DOI:10.1016/j.carbpol.2004.10.014

8. $\quad$ Singhal M and Ratra P, Global J Pharm., 2013, 7(2), 118-122.

9. Castro S D, Caetano L R, Ferreira G, Padilha P M, Saeki M J, Zara L F, Martines A U and Castro G R, Ind Engg Chem Res., 2011, 50(6), 3446-3451; DOI:10.1021/ie101499e

10. Tsai S Y, Huang S J, Lo S H, Wu T P, Lian P Y and Mau J L, Food Chem., 2009, 113(2), 578-584; DOI:10.1016/j.foodchem.2008.08.034

11. Alothman M, Bhat R and Karim A A, Food Chem., 2009, 115(3), 785-788; DOI:10.1016/j.foodchem.2008.12.005

12. Shivashankar M, Rajeshwari S, Nagananda G S, Rajath S and Chandan N, Res Pharm., 2013, 3(6), 06-13.

13. William J B, J Chem Edu., 2007, 84(12), 1913-1914; DOI:10.1021/ed084p1913 